\begin{tabular}{ccc}
\hline & International Journal of Engineering \& Technology, $7(2.13)(2018) 322-327$ \\
SPC & International Journal of Engineering \& Technology \\
Website: $w w w . s c i e n c e p u b c o . c o m / i n d e x . p h p / I J E T$ & Research Paper \\
\hline
\end{tabular}

\title{
Estimating impact of financial incentives on construction waste production
}

\author{
Milad Pavopar \\ Higher Education Institute, Loghman Hakim, Golestan Province
}

\begin{abstract}
Due to destructive environmental effects of construction wastes and increasing amount of these wastes that are in conflict with sustainable development objectives, it is essential to adopt solutions in order to reduce such wastes regarding environment preservation. This study was conducted to examine impact of financial incentives on reducing construction wastes using pairwise comparisons. According to professional opinions and experience of experts in building industry based on the 7-point Likert scale, mean responses obtained to 4.93, 4.83, and 4.73 for waste materials (stone, tile, ceramic), ready mix concrete waste, and EPS (Expanded Polystyrene) waste, respectively. On the other hand, reliability of research instrument obtained at 0.77 using Cronbach's alpha test. Moreover, it is seen that the studied materials in this research assigned $41 \%$ contribution of constructing costs to themselves; of them, fittings and tiles, ceramics and stone assigned the highest constructing cost to themselves with $12 \%$ contribution. In fact, waste of materials in projects under the "total price" contract 30 $50 \%$ higher than projects under the "cost plus" contract. Increasing number of floors and area of construction project lead to average reduction in waste of materials from $4.4 \%$ to $1.4 \%$. Change in regional price of housing will changes materials used in construction based on different prices.
\end{abstract}

Keywords Financial Incentives; Construction Wastes; Waste of Materials; Construction Projects; Materials Recycling.

\section{Introduction}

More attentions have paid to reuse and recycling construction wastes in recent years in order to reduce wastes and preserve environment. However, this action is low efficient due to lack of requiring fields and conditions like suitable building workshop and classification facilities, inadequate experience in recycling process, lack of trained constructors, and lack of knowledge about reuse of materials besides environmental and safety principles [1]. Nowadays, construction waste management has been identified as an important action to preserve environment so that wastes resulted by constructing operations highly affect the environment threating safety and health. In addition, space allocated to wastes accumulation is reducing. Building industry produces considerable waste daily about $40 \%$ accumulated wastes [2]. High amount of usable materials are lost due to accumulation space shortage; therefore, conventional methods are bot capable of controlling construction waste rate. Regarding sustainable development and regional capacity maintenance, it is essential to employ new constructing technologies and methods in order to reduce waste effectively. In this sense, prefabrication has been broadly used in developed countries [3]. Construction projects now form the artificial area in which, individuals live and work. About $95 \%$ of people living in developed countries work in such area and almost $80 \%$ of their GDP are produced in these places [4]. Performance of construction projects and lifetime management of constructed properties can affect the productivity, competitive power, quality of life and ecological sustainability of a country [5]. Nonetheless, many countries face important challenges in terms of construction projects performance and constructed properties [6]. Financial incentives in construction projects are named as key methods to improve environment outcomes. Financial incentives for construction projects are used to stimulate achieving goals beyond the business as usual (BAU) creating opportunity for contractor to gain more profits in case of achieving higher business performance [7]. Three types of financial incentives are used in construction contracts [8]: [1]. Incentives related to savings transfer in which, costs savings are distributed based on an agreement between client and contractor; [2]. Time incentives as rewards for early project completion by contractor; [3]. Considering reward for technical performance regardless of cost and schedule incentives. Complicated supply chain of construction products is one significant challenge to financial incentives for projects teams [9]. Therefore, financial incentives not only are essential to strengthen individual and organizational motivations but also are required to promote integrated motivation of project teams that are highly dependent to each other but independent contractually. Various actors like contractors, designers, form these teams and suppliers gathered in a situation with limit time to develop their relationships through time. Difficult process of evaluating dependent teams' performance can increase problems since it is not possible to distinguish individual and group [10]. Academic business commentators have claimed that performance incentives can improve project results for key clients and agents (consultants and contractors) [11]. Despite the mentioned advantages of financial incentives, project managers have not had enough construction information about effective implementation of these incentives. Although importance of team incentives and client qualification has been emphasized in relevant literature, there is not any accurate study on implementing these changes to achieve maximum level of advantages. In fact, there are few empirical studies about impact of these incentives on motivation and performance in scope of construction projects. 


\section{Theoretical foundations}

The issue of recycling and environmental pollutions is the case in many countries. Recycled materials consist of a wide range of urban and industrial garbage besides materials remained from old buildings destruction. One of significant problems in developed or developing countries in recent years is mass construction debris. Cities have been developed and old texture has been replaced with new buildings increasing construction debris production due to increasing land and house value added in large cities and high investment in this sector [12]. Since there is an increase in urban garbage and materials such as building destruction debris besides old texture of city especially in megacities and numerous issues caused by nonnormative and non-technical materials disposal, these materials should be recycled. In addition, increased price of construction materials in recent years and expanded productivity of construction industry in Iran have made employers and contractors to find a method in order to reduce construction costs of themselves and relevant organizations regarding reduction in environmental impacts of these construction wastes [13]. Construction waste recycling and management programs can be implemented to increase efficiency of construction materials and environmental pollutions.

Materials composition and constituents should be evaluated after determining necessity of waste recycling. To achieve this goal, existing urban wastes should be continuously tested and obtained results should be statistically examined; however, results highly depend on the sampling place and social-geographical conditions. Ultimately, technical properties of these materials should be determined besides location and application method of them. For this purpose, similar studies conducted in other countries can be reviewed to obtain an effective idea to use these materials [14]. In opinion of experts, this sector is directly or indirectly effective in job creation and being active so that its promotion can lead to flourishing industries. Obviously, systematic construction means correct use of building materials, financial sources, time and energy preventing from loss of heavy investments in buildings managing resources and time. Waste of materials will be prevented using principled production methods [15]. If high quality, standard and durable construction materials are used in building, early destruction will not happen and required materials for reconstruction or repair operations will be reduced [16]. There have been numerous studies in this field; some are mentioned herein:

In [17] studied reasons for increased construction materials debris and presented optimal solutions for reuse in 30 construction sites in Khuzestan, Tehran and Khorasan, Iran. Sample size calculated using Cochrane formula and verified using Morgan table based on the existing active labors. Results obtained from Friedman test were matched with t test in terms of impact percent on increasing construction wastes. Pearson correlation test was used to examine impact factor of variables based on correlation coefficient of -1 and $+(\mathrm{r}) 1$ and it was found that rules and regulations besides culture making had the highest effect on increasing construction materials waste, while construction condition had the lowest impact percent. In [16] concluded that recycling and reuse methods for construction materials have been less considered in Iran unfortunately. In this regard, management planning in field of waste recycling and construction debris reuse contributes to increased materials efficiency in building industry. This study aimed at examining factors and criteria affecting construction waste management based on the sustainable development implications. Results obtained from statistical analysis indicated that all of identified factors and questions were significant playing a key role in construction waste management. Inaccurate maintenance methods and low quality of produced materials identified as the most important factors in waste production with means 96.3 and 92.3, respectively; it can be stated that prevention is more effective that treatment so that correct packaging leads to increased quality of produced materials and declined construction waste production rate.

In [10] expressed that construction industry is one underlying economic sector of every society and this industry consumes a large volume of raw materials and produces large amounts of wastes annually. Optimal waste management is essential for environmental preservation. Optimized consumption of construction materials using construction waste management solutions not only reduces costs but also protects environment. Recycling is a challenging method as one waste management solution in many developing countries; hence, feasibility of recycling and its economical side is the case.

In [9] found that increasing price of raw materials and irreversible long-term damages to environment made the construction waste recycling an important subject. On the other hand, overuse of natural resources to construct roads, concrete, brick and other construction materials leads to natural materials shortage. Recycled materials can be reused adding higher quality materials. Microsilica is a Pozzolan that is widely used in concrete industry so that this substance reduces concrete permeability, increases concrete electrical resistance, increases compressive strength and concrete durability. In this research, sand was replaced with recycled aggregates and an optimum percent of microsilica (10-15\%) added to it to improve some concrete properties then strength of concrete was examined based on water to cement ratio and cement content; then, the constructed sample were examined in case of tensile, compressive and flexural strengths in days 3, 7 and 28 and obtained results showed that produced concretes by recycled aggregates containing microsilical with higher tensile, compressive and flexural strengths $(16 \%$, $13.6 \%, 12.9 \%)$ compared to concrete containing recycled aggregates.

Main Question

How is the impact of financial incentives on construction wastes production?

Secondary Questions

- What are higher wasteful materials in conventional steel and concrete buildings?

- How is the priority of wasteful materials in conventional steel and concrete structures?

- How the cost of materials waste and wasteful substances is estimated in steel and concrete buildings?

- What is the minimum rate of motivation to replace wasteful materials or lower use of them in construction?

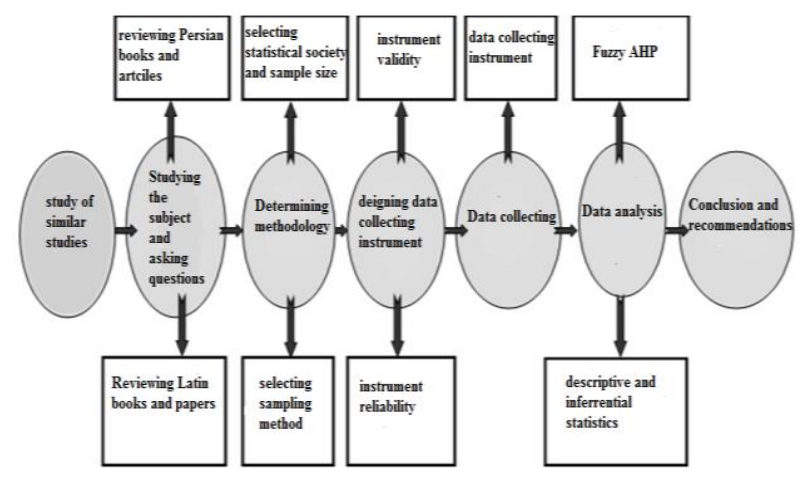

Fig. 1: Research Process

\section{Methodology}

This study estimated impact of financial incentives on construction waste production using Fuzzy AHP method. This was an applied research in terms of objective and a descriptive-correlational ranking study in terms of data collecting method. Statistical society of study comprised two groups: first group consisted of university professors in construction and construction waste recycling scopes and second group consisted of experts and civil engineers working in construction projects. Considering the specialized subject, questionnaire was employed and to collect and provide relevant literature and research background, library method was used. Two sampling methods including non-probabilistic purposeful sampling and snowball method were used. Sample size consisted of available experts who tend to collaborate on the subject. To determine validity 
of questionnaires, content validity method was used and to examine reliability, Cronbach's alpha coefficient was used. Ultimately, SPSS software was employed to examine impact of financial incentives estimation on construction waste production then Fuzzy AHP method was used through SuperDecisions Software since ranking of wasteful materials in building is a strategic decision.

\section{Findings}

Statistical population of study comprised university professors in construction engineering scope and individuals working in construction field or similar positions; since experts should be enough knowledgeable about the subject in order to be involved in process, 30 members having two characteristics (being familiar with the subject and having more than 3 years' work experience) were selected through purposeful non-probabilistic sampling method. Table below summarizes demographic description of research sample: Data Analysis To describe data, mean and standard deviation of them were used. According to table 2 and professional opinions of experts in building industry based on the 7-point Likert scale, mean responses obtained to $4.93,4.83$, and 4.73 for waste materials (stone, tile, ceramic), ready mix concrete waste, and EPS (Expanded Polystyrene) waste, respective-ly. Mean of Cronbach's alpha coefficients obtained above 0.777 indicated reliable professional opinions of experts in construction industry. To examine impressibility and effectiveness between dependent variable and independent variable, Pearson correlation coefficient was used based on the research variables. Table 4 indicates correlation between wasteful materials. Ranking research variables using Fuzzy AHPFirst step-AHP modeling Variables related to each factor was determined then the localized instrument (questionnaire) for variables that its reliability had been tested distributed. The localized questionnaire of variables used for hierarchical analyses and multi-criteria decision-making is called expert local-ized instrument for research components. One expert localized instrument for research components is prepared at each level of hierarchies. 9-point scale was employed for scoring.

Table 1: Summary of Sample's Demographic Description

\begin{tabular}{|c|c|c|c|c|}
\hline Row & Specifications type & Specifications & Number & Relative frequency (\%) \\
\hline \multirow{3}{*}{1} & \multirow{2}{*}{ Gender } & Male & 28 & 0.93 \\
\hline & & Female & 2 & 0.07 \\
\hline & & BA & 18 & 0.60 \\
\hline \multirow[t]{3}{*}{2} & \multirow[t]{3}{*}{ Academic degree } & MA & 10 & 0.33 \\
\hline & & $\mathrm{PhD}$ & 2 & 0.07 \\
\hline & & $3-5$ years & 20 & 0.67 \\
\hline \multirow[t]{2}{*}{3} & Relevant work experience & $6-10$ years & 8 & 0.26 \\
\hline & & More than 10 years & 2 & 0.07 \\
\hline
\end{tabular}

Table 2: Descriptive Data Related to Wasteful Construction Materials

\begin{tabular}{|c|c|c|c|c|c|c|}
\hline Wasteful construction materials & Number of data & Min & Max & Mean & Sd. & Skewness \\
\hline Brick, block, clay & 30 & 1 & 6 & 4.67 & 1.422 & -1.441 \\
\hline Cement, plaster, soil & 30 & 1 & 6 & 4.40 & 1.192 & -0.859 \\
\hline Gypsum board & 30 & 1 & 6 & 4.53 & 1.383 & -0.828 \\
\hline EPS & 30 & 1 & 6 & 4.73 & 1.230 & -1.238 \\
\hline Stone, tile, ceramic & 30 & 3 & 6 & 4.93 & 0.868 & -0.881 \\
\hline Pipes and installations & 30 & 2 & 6 & 4.67 & 1.155 & -.725 \\
\hline Fittings & 30 & 3 & 6 & 4.53 & 1.042 & -0.487 \\
\hline Ready mix concrete & 30 & 2 & 6 & 4.83 & 1.085 & -1.034 \\
\hline
\end{tabular}

Table 3: Reliability Data Using Cronbach's Alpha Test

\begin{tabular}{lll}
\hline Research variables & Cronbach's alpha coefficient & Number of items \\
\hline Construction materials & 0.777 & 8
\end{tabular}

Table 4: Correlation between Variables

\begin{tabular}{|c|c|c|c|c|c|c|c|c|c|}
\hline \multicolumn{2}{|c|}{ Correlation between variables } & \multicolumn{8}{|c|}{ Wasteful construction materials } \\
\hline \multirow{2}{*}{ Brick, block, clay } & Pearson coefficient & 1 & 0.529 & 0.812 & 0.263 & 0.121 & 0.224 & 0.078 & 0.342 \\
\hline & Sig. & & 0.003 & 0.001 & 0.021 & 0.044 & 0.004 & 0.034 & 0.024 \\
\hline \multirow{2}{*}{ Cement, plaster, soil } & Pearson coefficient & 0.529 & 1 & 0.473 & -0.019 & 0.493 & 0.150 & 0.600 & -0.053 \\
\hline & Sig. & 0.003 & & 0.008 & 0.021 & 0.006 & 0.028 & 0.000 & 0.030 \\
\hline \multirow{2}{*}{ Gypsum board } & Pearson coefficient & 0.812 & 0.473 & 1 & 0.330 & 0.203 & 0.288 & 0.131 & 0.429 \\
\hline & Sig. & 0.000 & 0.008 & & 0.045 & 0.002 & 0.023 & 0.001 & 0.018 \\
\hline \multirow{2}{*}{ EPS } & Pearson coefficient & 0.263 & -0.019 & 0.330 & 1 & 0.144 & 0.299 & 0.007 & 0.431 \\
\hline & Sig. & 0.161 & 0.021 & 0.005 & & 0.047 & 0.008 & 0.050 & 0.018 \\
\hline \multirow{2}{*}{ Stone, tile, ceramic } & Pearson coefficient & 0.121 & 0.493 & 0.203 & 0.144 & 1 & 0.149 & 0.651 & 0.207 \\
\hline & Sig. & 0.024 & 0.006 & 0.002 & 0.047 & & 0.032 & 0.000 & 0.042 \\
\hline \multirow{2}{*}{ Pipes and installations } & Pearson coefficient & 0.224 & 0.150 & 0.288 & 0.299 & 0.149 & 1 & 0.382 & 0.724 \\
\hline & Sig. & 0.034 & 0.028 & 0.023 & 0.008 & 0.032 & & 0.037 & 0.000 \\
\hline \multirow{2}{*}{ Fittings } & Pearson coefficient & 0.078 & 0.600 & 0.131 & 0.007 & 0.651 & 0.382 & 1 & 0.081 \\
\hline & Sig. & 0.004 & 0.000 & 0.001 & 0.050 & 0.000 & 0.037 & & 0.029 \\
\hline \multirow{2}{*}{ Ready mix concrete } & Pearson coefficient & 0.342 & -0.053 & 0.429 & 0.431 & 0.204 & 0.724 & 0.081 & 1 \\
\hline & Sig. & 0.044 & 0.030 & 0.018 & 0.018 & 0.065 & 0.000 & 0.049 & \\
\hline
\end{tabular}

Table 5: Expert Paired Comparison Instrument for Paired Comparison between Options

\begin{tabular}{lll}
\hline Value & Comparison between $\mathrm{i}$ and & Explanation \\
\hline 1 & Equally preferred & Criterion $\mathrm{i}$ is as important as criterion $\mathrm{j}$ and are equally preferred to each other \\
3 & Moderately preferred & Criterion i is a little important than $\mathrm{j}$ \\
5 & Strongly preferred & Criterion $\mathrm{i}$ is more important than $\mathrm{j}$ \\
7 & Very strongly preferred & Criterion $\mathrm{i}$ is strongly more important than $\mathrm{j}$ \\
9 & Extremely preferred & Criterion i is absolutely more important and cannot be compared with $\mathrm{j}$ \\
$2-4-6-8$ & Intermediate & Indicating intermediate values; for instance, 8 shows higher importance than 7 and lower than 9 for criterion \\
\hline
\end{tabular}


Table 6: Paired Comparison Instrument with AHP Method Wasteful Materials in Steel and Concrete Buildings

\begin{tabular}{|c|c|c|c|c|c|c|c|c|c|}
\hline & & Wasteful m & ials in steel and & oncrete bu & ngs & & & & \\
\hline Pairwise co & isons & $\begin{array}{l}\text { Brick, } \\
\text { block, clay }\end{array}$ & $\begin{array}{l}\text { Cement, plas- } \\
\text { ter, soil }\end{array}$ & $\begin{array}{l}\text { Gypsum } \\
\text { board }\end{array}$ & EPS & $\begin{array}{l}\text { Stone, tile, } \\
\text { ceramic }\end{array}$ & $\begin{array}{l}\text { Pipes and in- } \\
\text { stallations }\end{array}$ & $\begin{array}{l}\text { Fit- } \\
\text { tings }\end{array}$ & $\begin{array}{l}\text { Ready mix } \\
\text { concrete }\end{array}$ \\
\hline & $\begin{array}{l}\text { Brick, block, } \\
\text { clay }\end{array}$ & 1 & & & & & & & \\
\hline & $\begin{array}{l}\text { Cement, plas- } \\
\text { ter, soil }\end{array}$ & & 1 & & & & & & \\
\hline & Gypsum board & & & 1 & & & & & \\
\hline & EPS & & & & 1 & & & & \\
\hline concrete & $\begin{array}{l}\text { Stone, tile, ce- } \\
\text { ramic }\end{array}$ & & & & & 1 & & & \\
\hline & $\begin{array}{l}\text { Pipes and in- } \\
\text { stallations }\end{array}$ & & & & & & 1 & & \\
\hline & Fittings & & & & & & & 1 & \\
\hline & $\begin{array}{l}\text { Ready mix } \\
\text { concrete }\end{array}$ & & & & & & & & 1 \\
\hline
\end{tabular}

Second step- ranking materials using AHP method based on experts' opinions. First step of hierarchies is formed by main criteria Expert localized instrument for research variables compares main criteria in pairwise method based on the objective then determines priority of each main criterion.

Third step- hierarchical analysis and ranking wasteful materials in steel and concrete buildings based on the analyses of Super Decisions Software: to determine priority, normalization method was used. After normalizing, weight of each option was obtained based on the considered criterion. In this regard, priority of each option is calculated based on the above-mentioned criteria. Priority is the case herein. Figure and table below demonstrate hierarchy analysis and prioritizing wasteful construction materials.

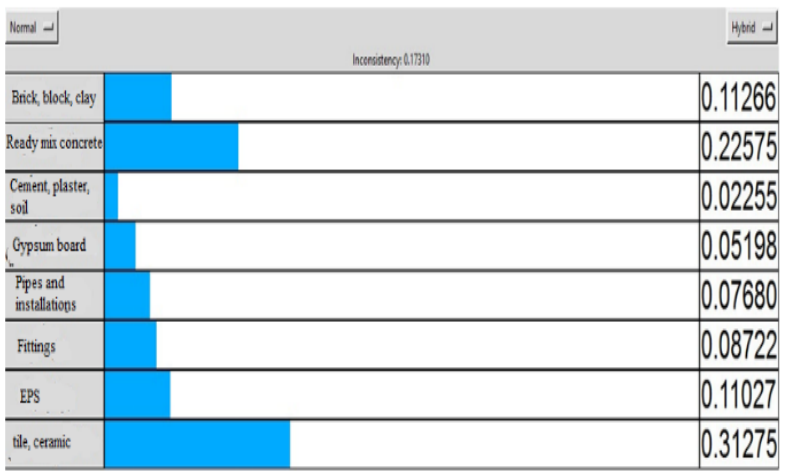

Fig. 2: Prioritizing Wasteful Construction Materials Based on Opinions of Experts in Construction Scope

Table 7: Prioritizing Wasteful Construction Materials Based on Opinions of Experts in Construction Scope.

\begin{tabular}{lll}
\hline Rank & Criterion & Criterion weight \\
\hline 1 & Stone, tile, ceramic & 0.312 \\
2 & Ready mix concrete & 0.225 \\
3 & Brick, block, clay & 0.112 \\
4 & EPS & 0.110 \\
5 & Fittings & 0.087 \\
6 & Pipes and installations & 0.076 \\
7 & Gypsum board & 0.051 \\
8 & Cement, plaster, soil & 0.022 \\
\hline
\end{tabular}

According to the final analysis and prioritizing wasteful materials in steel and concrete buildings, "stone, tile and ceramic", "ready mix concrete" and "brick, block, clay" were identified as the most important wasteful materials with weights $0.312,0.225$ and 0.112 , respectively.

Fourth step- prioritizing wasteful materials in steel and concrete buildings. The following table and figure indicate linguistic variables, fuzzy values and membership functions of relevant triangular and trapezoidal numbers within a 7-point scale.

Table 8: Linguistic Variables Related to Research Variables

\begin{tabular}{ll}
\hline Linguistic variable & $\begin{array}{l}\text { membership functions of triangular and trapezoi- } \\
\text { dal numbers }\end{array}$ \\
\hline Unimportant & $(0.00 .00 .0250 .5)$ \\
\hline
\end{tabular}

\begin{tabular}{ll}
\hline Very weak & $(0,0.50 .100 .15)$ \\
Weak & $(0.10 .20 .3)$ \\
Medium & $(0.30 .50 .7)$ \\
High importance & $(0.70 .80 .9)$ \\
Very high im- & $(0.850 .90 .95)$ \\
portance & $(0.9250 .9511)$ \\
Excellent & \\
\hline
\end{tabular}

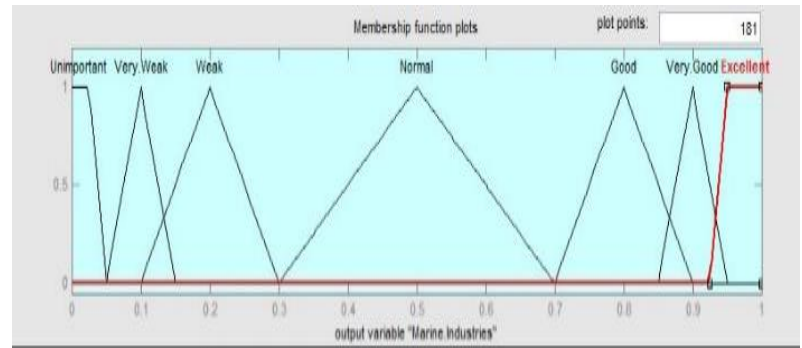

Fig. 3: Partitioning Criteria and Determining Fuzzy Values Related to Linguistic Variables (Membership Functions of Triangular and Trapezoidal Numbers).

Moreover, fuzzy weights and fuzzy ranking of wasteful materials in steel and concrete buildings are indicated in table 9.

Table 9: Fuzzy Weights and Fuzzy Ranking of Wasteful Materials in Steel and Concrete Buildings

\begin{tabular}{|c|c|c|c|c|}
\hline Row & $\begin{array}{l}\text { Research } \\
\text { criteria }\end{array}$ & $\begin{array}{l}\text { Criteria } \\
\text { weights based } \\
\text { on AHP }\end{array}$ & $\begin{array}{l}\text { Fuzzy weight } \\
\text { based on lin- } \\
\text { guistic variables }\end{array}$ & $\begin{array}{l}\text { Final } \\
\text { weight of } \\
\text { criterion }\end{array}$ \\
\hline 1 & $\begin{array}{l}\text { Stone, tile, } \\
\text { ceramic }\end{array}$ & 0.312 & 0.704 & 0.219 \\
\hline 2 & $\begin{array}{l}\text { Ready } \\
\text { mix con- } \\
\text { crete }\end{array}$ & 0.225 & 0.69 & 0.155 \\
\hline 3 & $\begin{array}{l}\text { Brick, } \\
\text { block, } \\
\text { clay }\end{array}$ & 0.112 & 0.667 & 0.074 \\
\hline 4 & EPS & 0.110 & 0.675 & 0.074 \\
\hline 5 & Fittings & 0.087 & 0.647 & 0.056 \\
\hline 6 & $\begin{array}{l}\text { Pipes and } \\
\text { installa- } \\
\text { tions }\end{array}$ & 0.076 & 0.667 & 0.050 \\
\hline 7 & $\begin{array}{l}\text { Gypsum } \\
\text { board }\end{array}$ & 0.051 & 0.647 & 0.033 \\
\hline 8 & $\begin{array}{l}\text { Cement, } \\
\text { plaster, } \\
\text { soil }\end{array}$ & 0.022 & 0.628 & 0.013 \\
\hline
\end{tabular}

Weight and fuzzy prioritization of materials have been shown in table 9; final value is obtained from criteria weight based on AHP multiplied by fuzzy weight based on linguistic variables.

Materials waste percentage

32 residential $4-7$ story buildings with $50-230 \mathrm{~m} 2$ areas in [7] regions of Tehran, Iran were monitored to collect data related to waste of materials. It should be noted that these buildings were tested at different steps like skeleton and walls fabrication, installations, façade fabrication, and end of work in order to cover all of construction steps dynamically without missing executive steps due to time 
gap until project ending and lack of contractors' domination. The obtained results are described in table 10 .

Table 10: Materials Waste Percentage

\begin{tabular}{|c|c|c|c|c|c|c|c|c|c|c|}
\hline $\begin{array}{l}\text { Total } \\
(\%)\end{array}$ & EPS & $\begin{array}{l}\text { Pipes and in- } \\
\text { stallations }\end{array}$ & $\begin{array}{l}\text { Plaster } \\
\text { and soil }\end{array}$ & $\begin{array}{l}\text { Stone, tile, } \\
\text { ceramic }\end{array}$ & $\begin{array}{l}\text { Brick, } \\
\text { block, clay }\end{array}$ & $\begin{array}{l}\text { Gypsum } \\
\text { board }\end{array}$ & $\begin{array}{l}\text { Ready mix } \\
\text { concrete }\end{array}$ & $\begin{array}{l}\text { Fit- } \\
\text { tings }\end{array}$ & $\begin{array}{l}\text { Materials } \\
\text { name }\end{array}$ & \\
\hline & 5 & 6.1 & 6.6 & 2.4 & 5.7 & 1.5 & 6.2 & 1 & $\begin{array}{l}\text { Total price } \\
\text { method }\end{array}$ & \multirow{2}{*}{$\begin{array}{l}\text { Materials waste } \\
\text { percentage }\end{array}$} \\
\hline & 5.7 & 2.2 & 4.8 & 5.6 & 1.11 & 9.6 & 4 & 4.1 & $\begin{array}{l}\text { Cost plus } \\
\text { method }\end{array}$ & \\
\hline 41 & 1 & 4 & 4 & 12 & 2 & 2 & 4 & 12 & \multicolumn{2}{|c|}{$\begin{array}{l}\text { Contribution percent of each } \\
\text { item in building cost }\end{array}$} \\
\hline 3.3 & 0.05 & 0.06 & 0.26 & 0.50 & 0.15 & 0.10 & 0.10 & 12 & $\begin{array}{l}\text { Total price } \\
\text { method }\end{array}$ & $\begin{array}{l}\text { Lost cost per- } \\
\text { centage }\end{array}$ \\
\hline 4.8 & 0.08 & 0.09 & 0.24 & 0.78 & 0.22 & 0.14 & 0.16 & 0.16 & $\begin{array}{l}\text { Cost plus } \\
\text { method }\end{array}$ & \\
\hline
\end{tabular}

According to table 10, the examined materials in this research assigned $41 \%$ contribution of construction costs to themselves; of them, fittings and tile, ceramic and stone had the highest cost of construction each with $12 \%$ contribution.

\section{Discussion and conclusion}

According to professional opinions of experts in construction industry based on a 7-point scale, mean responses obtained to 4.93 , 4.83, and 4.73 for waste materials (stone, tile, ceramic), ready mix concrete waste, and EPS (Expanded Polystyrene) waste, respectively. On the other hand, inconsistency rate indicates reliability level of priorities obtained from comparisons. According to final analysis and prioritization of types of wasteful materials in steel and concrete buildings, the lower inconsistency rate was obtained (0.173). According to final analysis and prioritization of wasteful materials in steel and concrete buildings, "stone, tile and ceramic", "ready mix concrete" and "brick, block, clay" were identified as the most important wasteful materials with weights $0.312,0.225$ and 0.112 , respectively.

The most substantial result of this study on estimating impact of financial incentives on construction waste production indicated positive and significant relation between "brick, block, clay" and "gypsum board" since correlation coefficient sign is regression line slope, because Pearson correlation coefficient between these variables obtained to 0.812 . There was also a positive and significant relation between "stone, tile and ceramic" and "fittings" considering their Pearson correlation coefficient 0.651 ; there was a positive and significant relation between "pipes and installations" and "ready mix concrete" since the Pearson correlation coefficient between them obtained to 0.724 . As it was mentioned, the examined materials in this research assigned $41 \%$ contribution of construction costs to themselves; of them, fittings and tile, ceramic and stone had the highest cost of construction each with $12 \%$ contribution. Waste of materials in projects under the cost plus contract (contract management) is higher than projects under the total price contract. Difference rate of waste in two contract types varies based on the materials type. For instance, in covenant management contracts compared to total price contract, waste rates obtained to $30 \%, 54 \%$, $35 \%, 48 \%, 55 \%, 27 \%, 38 \%$ and $50 \%$ for fittings, ready mix concrete, gypsum boards, brick and clay, stone and ceramic, plaster, sand and cement, pipes and installations, and EPS, respectively. Seemingly, there is an increase in materials waste (more than 50\%) in terms of ready mix concrete, stone, tile, and ceramic. According to the obtained results, $41 \%$ of construction projects' costs assigned to massive materials indicating considerable effect of materials waste on construction costs. Monetary value of different materials indicates different project costs waste. Materials waste percent was calculated based on building utility considering the price of each $\mathrm{m} 2$ area of building (per 10 million rial). Materials waste is $30-50 \%$ higher in projects under the cost plus contract compared to projects under the total price contract. Increasing number of stories and area of construction projects average rate of materials waste reaches from $4.4 \%$ to $1.4 \%$; hence, change in regional price of housing leads to change in amount of materials used in construction projects based on different prices.

Recommended solutions to reduce fittings waste

- Accurate designing by calculator engineer to minimize wastes

- Correcting design when implementing in order to optimize fittings dimensions

- Purchasing materials based on the stock inventory and site conditions

- Using appropriate methods to carry product

- Accurate measurement and cutting fittings in construction site

- Using wastes resulted by cutting fittings

- Solutions to reduce concrete waste

- Accurate calculation of required concrete

- Using remained concrete in concrete pomp and its pipes

- Returning surplus concrete to other sites

- Using frames without any fracture

- Employing skilled forming and concreting contractors Solutions to reduce waste of brick, clay and block

- Using skilled workers

- Supervision over implementation process

- Preventing from rework

- Suitable carriage and maintenance

- Solutions to reduce waste of gypsum boards:

- Employing skilled labors

- Supervision over implementation process Solutions to reduce waste of stone, tile and ceramic:

- $\quad$ Using skilled workers

- Suitable carriage and maintenance

- Solutions to reduce waste of cement, plaster and sand:

- Employing skilled labors

- Supervision over workers

- Suitable carriage and maintenance Solutions to reduce waste of pipes and other installations:

- Employing skilled labors

- Selecting the best path for pipe passing

- Relatively accurate estimation of pipe size and other installations

\section{References}

[1] Sajedi, S. F., Yavari, A. (2016). An analysis of the causes of increased waste of building materials in Iran, International Conference on Civil Engineering, Tehran, Permanent Secretariat of the Conference.

[2] Sajedi, S. F., Yavari, A. (2016). Management of reducing construction waste materials in in Iran, First International Conference and 3rd National Conference on Architecture and Sustainable Urban Landscape, Mashhad, International Institute of Architecture, Urban Planning, Mehraz Shahr.

[3] Heyrati, A., Abbasian, H. (2016). Construction waste management based on the concepts of sustainable development, Second International Conference on Architecture, Civil and Urban Development at 
the Beginning of the Third Millennium, Tehran, Consortium of the City of Architecture and Urban Development of the Alborz Province, Society of Urban Engineers of the Banshahr Institute Sustainable Salvi Nasr Cultural and Cultural Institute.

[4] Sabt, M. H., Shah Hosseini, V., Nikkhah Manesh, S. (2015). Economic feasibility of waste recycling, Tenth International Congress of Civil Engineering, Tabriz, Tabriz University, Faculty of Civil Engineering.

[5] .Iani, I., Fallah, A. A., Mirjalili, A. (2015). Investigating methods and models for quantitative estimation of construction wastes, 10th International Congress on Civil Engineering, Tabriz, Tabriz University, and Faculty of Civil Engineering.

[6] Nikmehr, B., Ghodousi, P., Hosseini, M. R. (2016). Study on the status of waste management in Tehran, the preliminary results, International Conference on New Achievements in Civil Engineering, Architecture, Environment and Urban Management, Tehran, Institute of Managers of Idea Capital, Vieira.

[7] Zahrabi, A., Ameri, F., Zahrabi, M. (2015). Investigation of the effect of microsilica on concrete composed of construction wastes, International Conference on Science, Engineering and Environmental Technologies, Tehran, Faculty of Environment, University of Tehran.

[8] Bagheri Kakesh, K., Fallah, A. A., Mirjalili, A. (2015). Construction waste management resulted by fabrication and destruction, The first scientific-scientific congress of modern horizons in the field of Civil Engineering, Architecture, Culture and Urban Management of Iran, Tehran, Association for the Promotion of Science and Technology Fundamental Techniques.

[9] Yavari, A. (2015). Study on the causes of increasing waste of building materials and providing solutions for their optimization, Second National Conference on Environmental Health, Health and Sustainable Environment, Hamedan, Permanent Secretariat of the Conference, Mofattah Shahid Faculty.

[10] Manseau A, Seaden G. Innovation in construction: an international review of public

Policy. New York, NY: Spon Press; 2001.

[11] Construction innovation. In: Newton P, Hampson K, Drogemuller R, editors. Technology, design and process innovation in the built environment. Abingdon: Taylor and Francis; 2009. p. 3-28.

[12] Rahman MM, Kumaraswamy MM. Contracting relationship trends and transitions. J Manage Eng 2004 20(4): 147-61.

[13] Sliwka D. On the hidden costs of incentive schemes. IZA Discussion Paper, No. 844. Bonn: Institute for the Study of Labor; 2003.

[14] Bower D, Ashby G, Gerald K, Smyk W. Incentive mechanisms for project success. J Manage Eng 2002; 18(1): 37-43.

[15] Howard WE, Bell LC, McCormick RE. Economic principals of contractor compensation. J Manage Eng 1997 13(5): 81-9.

[16] Howard LW, Turban DB, Hurley SK. Cooperating teams and competing rewards strategies: incentives for team performance and firm productivity. J Behav Appl Manage 2002 3(3): 248-63. 